\title{
Guidance and Counseling Services to Improve Student Resilience
}

\author{
Denok Setiawati ${ }^{1, *}$ \\ ${ }^{1}$ Universitas Negeri Surabaya \\ ${ }^{*}$ Corresponding author. Email: denoksetiawati@unesa.ac.id
}

\begin{abstract}
The purpose of this study is to describe the resilience of junior high school students and the types of services that can be applied to improve the resilience of junior high school students. This research is a quantitative descriptive study with data collection techniques are resilience scales, and interviews. There are two sources of this research. There are 44 junior high school students, namely primary sources, and six school counselors as secondary primary sources. The results of the resilience scale show that $48.18 \%$ of students have high resilience and $58.82 \%$ have moderate/medium resilience. The services that can improve resilience are classical guidance, group guidance, individual counseling, and group counseling. This research can be used as initial data to provide intervention in providing guidance and counseling services to students who have low resilience.
\end{abstract}

Keywords: Student Resilience, Guidance and Counseling Services, School Counselors.

\section{INTRODUCTION}

Resilience for students is very important because someone who has good resilience will positively impact their psychosocial development, especially to realize psychological well-being. Resilience is related to the ability to survive, adapt to something stressful, overcome and go through, and be able to recover from adversity[1]. Various studies on resilience show a need for high resilience, and the advantages of having high resilience will positively impact their psychosocial development.

Several studies on resilience (the urgency of resilience to be studied, its relation to psychosocial/psychological development/advance) indicate the need for high resilience and the advantages of having it. Someone who has high resilience will be more productive[2]-[4]. As stated by Garmezy that resilient people are those who work well and also play well[5]. In addition, other studies have also shown that resilience is also related to a person's mental health[6]. Conversely, someone with low resilience will experience psychological distress that impacts physical and mental health and even death.

Every individual has resilience at different levels. However, if it is not accompanied, then problems will arise. The Singgih study revealed that the failure of the large-scale social restriction (PSBB) policy in suppressing the Covid-19 rate in Surabaya in 2020 was due to the high level of resilience character in the community. The study above shows that there needs to be assistance for student resilience in order to develop properly. Several studies have shown that resilience can be increased through training or programs designed by schools. Student resilience is enhanced through innovative curricular and co-curricular activities, namely the program, informed by social cognition and political leadership theory[7].

Assistance can be provided by all parties, including school counselors, in the form of guidance and counseling services. Guidance and counseling have an important role for students to facilitate student development, one of which is assisting in increasing resilience or so that student resilience develops optimally and positively. Guidance and counseling have an important role in assisting optimal development for students so that students do not fall into existing problems because students are individuals who are developing or becoming (on becoming), which is developing towards maturity or independence[8]. In addition, guidance and counseling services in secondary schools are the most fertile setting for counselors because, at that level, counselors can play a leading role in facilitating counselees to actualize their potential [8] optimally. 
The formulation of the research problem is "how to describe the level of student resilience and what services can be applied to improve student resilience?"

\section{METHODS}

This research is quantitative research with a descriptive approach. Data collection methods are the Scale of resilience and interview. The Scale was derived from 7 indicators: emotion regulation, impulse control, optimism, causal analysis, empathy, self-efficacy, and reaching out. Furthermore, these indicators were developed into 14 items of statements, interviews, and literature studies. The resilience scale contains four possible answers: never with a value of 1 , rarely with a value of 2 , often with a value of 3 , and always with a value of 4 . After being circulated through the help of google form, all results are grouped into three categories for resilience based on indicators, namely a score of 4488 including low, 89-133 is medium, and 134-176 is high. As for individuals, they are grouped into three groups, namely 14-28 are individuals who have low resilience, 29-43 are moderate, while 44-56 are high.

Table 1. Result of the resilience scale
Descriptive research follows the steps of identifying problems, formulating and limiting the scope of the problem, determining research objectives and benefits, literature reviewing, determining research frameworks and hypotheses by research objectives, determining methods to be used in the research, collecting, organizing, and analyze research findings data with statistical techniques, make research reports based on systematics[9].

\section{RESULTS AND DISCUSSION}

The study results refer to the results of the resilience scale, interviews, and literature studies. The results of the research scale are presented in table 1 .

Based on the results of the resilience scale above, it shows that students have high resilience in terms of completing tasks well, confidence in achieving goals, knowing the cause and effect of actions taken, being easily touched by the suffering of others, willing to help friends who are experiencing difficulties, and sure to solve the problem well. If it is included in the resilience indicator, the high category is optimism, causal analysis,

\begin{tabular}{|l|l|l|c|}
\hline Number & Statement items & Result & Category \\
\hline 1 & I stay calm even though various problems come my way & 131 & Medium \\
\hline 2 & I can handle various pressures well & 123 & Medium \\
\hline 3 & Even though there are various pressures I can still control & 121 & Medium \\
\hline 4 & my emotions & 131 & Medium \\
\hline 5 & I am able to control the negative impulses within me & 140 & High \\
\hline 6 & I am able to complete my tasks well & 154 & High \\
\hline 7 & I'm sure I can achieve my goals well & 129 & Medium \\
\hline 8 & I know the cause of failure from the plan I made & 142 & High \\
\hline 9 & I can find out the cause and effect of my actions & 145 & High \\
\hline 10 & I am easily touched by the suffering of others & 144 & High \\
\hline 11 & I am willing to help my friend who is having trouble & 126 & Medium \\
\hline 12 & I'm sure I can solve my problem well & 128 & Medium \\
\hline 13 & I believe I am a person who solves my problems as well as & 132 & Medium \\
\hline
\end{tabular}

Interviews are used to reveal the importance of resilience to be optimally improved in various conditions and the types of services that can improve the resilience of junior high school students. The sampling technique is random sampling. There is 44 junior high school as primary sources, and six school counselors as secondary primary sources. and empathy. At the same time, the student resilience data is presented in table 2 . 
Table 2. Student resilience level data

\begin{tabular}{|c|c|c|}
\hline $\begin{array}{l}\text { Number of } \\
\text { students }\end{array}$ & Result & Category \\
\hline 1 & 44 & High \\
\hline 2 & 39 & Medium \\
\hline 3 & 41 & High \\
\hline 4 & 35 & Medium \\
\hline 5 & 45 & High \\
\hline 6 & 41 & Medium \\
\hline 7 & 51 & High \\
\hline 8 & 39 & Medium \\
\hline 9 & 48 & High \\
\hline 10 & 43 & Medium \\
\hline 11 & 47 & High \\
\hline 12 & 47 & High \\
\hline 13 & 40 & Medium \\
\hline 14 & 43 & Medium \\
\hline 15 & 35 & Medium \\
\hline 16 & 42 & Medium \\
\hline 17 & 53 & High \\
\hline 18 & 45 & High \\
\hline 19 & 48 & High \\
\hline 20 & 34 & Medium \\
\hline 21 & 48 & High \\
\hline 22 & 38 & Medium \\
\hline 23 & 51 & High \\
\hline 24 & 43 & Medium \\
\hline 25 & 45 & High \\
\hline 26 & 47 & High \\
\hline 27 & 51 & High \\
\hline 28 & 43 & Medium \\
\hline 29 & 31 & Medium \\
\hline 30 & 41 & Medium \\
\hline 31 & 50 & High \\
\hline 32 & 35 & Medium \\
\hline 33 & 47 & High \\
\hline 34 & 35 & Medium \\
\hline 35 & 45 & High \\
\hline 36 & 38 & Medium \\
\hline 37 & 41 & Medium \\
\hline 38 & 41 & Medium \\
\hline 39 & 43 & Medium \\
\hline 40 & 42 & Medium \\
\hline
\end{tabular}

\begin{tabular}{|l|l|l|}
\hline 41 & 39 & Medium \\
\hline 42 & 40 & Medium \\
\hline
\end{tabular}

Based on the results in table 2, 19 students have high resilience, and 25 students have high resilience.

The results of interviews with counselors indicate that student resilience needs to be improved with various services, especially basic services and responsive services such as classical guidance, group guidance, individual counseling. Comprehensive guidance and counseling have four service components: basic service components, responsive services, individual planning, and system support. At the same time, developmental guidance and counseling touch all aspects of the life or development of students [8].

Each service component has a service strategy, among others. Basic service is a component that is applied to assist with structured experience preparation activities both classically or in groups whose design and implementation are systematically carried out to develop effective self-adjustment abilities according to the stages and tasks development. The strategies in basic services are 1) classical guidance, 2) group guidance, 3) group guidance media, 4) needs assessment.

Individual planning is a guidance service that aims to help individuals make and implement plans for their education, career, and social personality[10]. This method helps individuals monitor and understand their growth and development for later planning and implementation of plans according to their monitoring and understanding. System support is one form of the component in the implementation of guidance and counseling programs that are carried out indirectly in order to provide assistance or facilitate the smooth development of counselees in order to facilitate the implementation of basic, responsive, and individual planning services in the form of consulting or collaboration services, management, networking[11].

The types of services that can be applied to improve resilience are basic services such as classical guidance services and group guidance services as research conducted on the effectiveness of group guidance with a system approach model to improve student resilience[12]. Other services that can be applied are responsive services such as counseling services such as the research conducted on the Effectiveness of the Ego Approach to Improve Student Self-Resilence at SMAN 2 Padang Panjang to accommodate Javanese "pitutur" values in BK services, namely basic services and responsive services[13]. Responsive services are assistance provided to individuals to deal with problems and assistance provided to individuals who need help immediately, hoping that students do not experience obstacles in achieving developmental tasks. Responsive 
service strategies can be in the form of individual counseling and group counseling.

\section{CONCLUSION}

Based on the results of research and discussion, it was obtained data that guidance and counseling services play an important role in increasing student resilience. The types of services that can improve student resilience include basic services such as classical guidance services and group guidance services. Other services that can also be applied are responsive services such as individual and group counseling. The research conducted can be used as an input in implementing counseling guidance services, especially in increasing student resilience. Further research can be focused on choosing the type of research; it can be experimental research or the development of models or guidelines to improve student resilience.

\section{REFERENCES}

[1] K. Reivich and A. Shatté, The resilience factor: 7 essential skills for overcoming life's inevitable obstacles. New York: Broadway Books, 2002.

[2] K. D. Hopkins, S. R. Zubrick, and C. L. Taylor, "Resilience amongst Australian aboriginal youth: an ecological analysis of factors associated with psychosocial functioning in high and low family risk contexts," PLoS One, vol. 9, no. 7, p. e102820., 2014, DOI: https://doi.org/10.1371/journal.pone.0102820.

[3] K. D. Hopkins, C. C. J. Shepherd, C. L. Taylor, and S. R. Zubrick, "Relationships between Psychosocial Resilience and Physical Health Status of Western Australian Urban Aboriginal Youth," PLoS One, vol. 10, no. 12, p. e0145382, 2015, DOI:

https://doi.org/10.1371/journal.pone.0145382.

[4] K. D.Hopkins, C. L.Taylor, and S. R.Zubrick, "Psychosocial resilience and vulnerability in Western Australian Aboriginal youth," Child Abuse Negl., vol. 78, pp. 85-95, 2018, DOI: https://doi.org/10.1016/j.chiabu.2017.11.014.

[5] K. L. Kumpfer, "Factors and processes contributing to resilience," in Resilience and Development: Positive Life Adaptations, Boston: Springer, 2002, pp. 179-224.

[6] L. Wexler, L. Joule, J. Garoutte, J. Mazziotti, and K. Hopper, "Being responsible, respectful, trying to keep the tradition alive: Cultural resilience and growing up in an Alaska Native community," Transcult. Psychiatry, vol. 51, no. 5, pp. 693-712, 2014 ,

DOI: https://doi.org/10.1177/1363461513495085.

[7] M. Brewer, G. van Kessel, B. Sanderson, and A. Carter, "Enhancing student resilience by targeting staff resilience, attitudes, and practices," High. Educ. Res. Dev., pp. 1-15, 2021, DOI: https://doi.org/10.1080/07294360.2021.1877622.

[8] Depdiknas, Penataan Layanan BK Pada Jalur Pendidikan Formal. Jakarta: Depdiknas, 2008.

[9] Sukardi, Metodologi Penelitian Pendidikan: Kompetensi dan Praktiknya. Jakarta: Bumi Aksara, 2021.

[10] A. J. Nurihsan, Bimbingan \& konseling dalam berbagai latar kehidupan. Bandung: PT. Refika Aditama, 2014.

[11] S. Yusuf, Program Bimbingan dan Konseling di Sekolah (SLTP dan SLTA). Bandung: Pustaka Ban iQuraisy, 2006.

[12] A. M. C. Ariyani, "Model Bimbingan Kelompok Berdasarkan Pendekatan Sistem untuk Meningkatkan Resiliensi Siswa," J. Bimbing. Konseling, vol. 1, no. 1, 2012, doi: 10.15294/JUBK.V1I1.76.

[13] W. Hafiva, F. Yusri, and W. Aprison, "Efektivitas Pendekatan Ego Untuk Meningkatkan Resiliensi Diri Siswa di SMAN 2 Padang Panjang," Islam. Couns. J. Bimbing. Konseling Islam. Bimbing. Konseling Islam, vol. 4, no. 2, pp. 223-236, 2020, doi: 10.29240/jbk.v4i2.1474. 